\title{
The use of satellite tv to improve students' english mastery at nu Sunan Giri University
}

\author{
Khoirul Wafa ${ }^{1}$ and Edi Suwandi ${ }^{1}$ \\ ${ }^{1}$ English Education Department, Universitas Nahdlatul Ulama Sunan Giri Bojonegoro, Indonesia
}

\begin{tabular}{l}
\hline \hline Article Info \\
\hline Article history: \\
Received Jul 30, 2019 \\
Revised Sept 20, 2019 \\
Accepted Oct 6, 2019 \\
\hline
\end{tabular}

Keywords:

Satellite TV;

Learning media;

English mastery.

\begin{abstract}
Technology is developing fast nowadays. All fields of life have implemented sophisticated technology, including agriculture, food processing, the automotive industry, and even entertainment. Technological competition actually has positive and negative impacts such as unemployment, cold war between countries, and terrorism. To follow news of the development of a country is actually very easy. The news can be seen on the web, social media and TV. One of the easiest is TV. To be able to follow the development of other countries through TV, can be seen through foreign TV channels. Some of the famous ones are NHK, Channel News Asia, France24, DW, Aljazeera, and Russia Today. This study aims to determine the process of teaching English using satellite TV and whether the use of satellite TV media can improve the students' English mastery. This study uses a Class Research (CAR) approach. The implementation model in this study uses four steps: identifying problems and planning actions; implementing actions and observing or monitoring actions; reflection of the results of observations; and revise plans for the next step. This research uses 2 cycles in the learning process. The subjects of this study were third semester students of the English Education Study Program at NU University, Sunan Giri Bojonegoro in the academic year of 2019/2020. This research was carried out in the room U8 of NU University, Sunan Giri Bojonegoro. The results of this study are: In the pre-test, the number of students who passed a total of 6 students $(17.14 \%)$ with an average score of 63.71 . In the first cycle, the number of students who passed was 19 students $(54.28 \%)$ with an average score of 73 . In the second cycle, the number of students who passed was 33 students (94.28\%) with an average score of 78.43. Based on the average score of the pre-test, cycle I, and cycle II it can be concluded that the use of satellite TV can improve the students' English mastery at NU Sunan Giri University.
\end{abstract}

Copyright $(2019$ Department of English Teaching. All rights reserved.

Corresponding Author:

Khoirul Wafa,

English Education Department, Universitas Nahdlatul Ulama Sunan Giri Bojonegoro, Indonesia

Jl. Jend. Ahmad Yani No.10, Jambean, Sukorejo, Kec. Bojonegoro, Kabupaten Bojonegoro.

Email: wafa.gitafsclub@gmail.com

\section{INTRODUCTION}

Technology is developing very fast nowadays. All fields of life have implemented sophisticated technology, including in agriculture, food processing, the automotive industry, and even entertainment. All countries compete to become the country with the most advanced technology. This technological competition is a positive thing. Sophisticated technology can facilitate human life in all fields. But there are also negative developments in technology such as unemployment, cold war between countries, and terrorism. Each country competes to become the country with the strongest economic and military power.

To follow news of the development of a country is actually very easy. The news can be seen on the web, social media and TV. One of them is TV. Dozens and even hundreds of TV channels broadcast news 
about the state and development of the world. To be able to follow the development of other countries through TV, it can be seen through international TV channels. Some of the famous ones are NHK, Channel News Asia, France24, DW, Aljazeera, and Russia Today. These TV channels can be seen with satellite TV. Television or commonly abbreviated with TV according to Kamus Besar Bahasa Indonesia is interpreted as a technological tool derived from the word "tele" which means far, and "visie" which means to see, which means "to see from afar". TV is often interpreted as a way of sending moving pictures or television signals from studios and transmitters to radio receivers. Satellite TV is a wireless system for delivering television programs directly to home viewers, while TV broadcasts and TV transmitters broadcast their programs via radio signals (Narmadi: 2016).

For students, mastering English is absolutely necessary. Considering that students are the next generation of the nation, future national leaders, and future national policy makers. In a way, the fate of a nation is also determined by the quality of students. What is the mindset of students, how they make decisions, and what they action and innovation. Therefore English learning has started from elementary level to university level. It is also a preparation to welcome the industrial revolution era 4.0.

Many students who study English do not fully understand English. Students still often have difficulty in understanding a discourse, grammar, dialogue, and essence of a reading. This is due to lack of interest, sincerity, and practice. So when students are confronted with real conditions in social life they still have weaknesses in self-confidence and language skills. This is very unfortunate if students as the next generation of the nation are not able to master English as an international language so they cannot follow the news of developments from all countries in the world, for example if there are news from other countries that have the potential to disturb the stability of the country and threaten national security.

In this research, the planned TV channels will be used as learning media, namely: Channel News Asia, NHK, France 24, and Russia Today. All of these channels use English and air 24 hours. The contents of these channels are international news across English-speaking countries so it is very suitable for learning. News that is broadcast is usually the current state of a country, disasters, other countries' security issues, technological developments, tourism, and many others. The channels are located on the K-Vision satellite TV

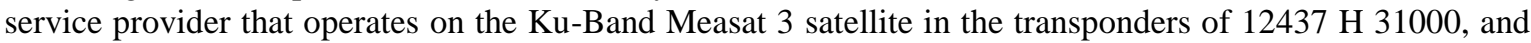
can be received easily using a simple satellite dish. The channels are available free of charge, so they can be applied in all schools or universities.

To improve mastery of English, researchers propose learning through the use of satellite TV media. The word media comes from the Latin "medius" which literally means middle, intermediary, or introduction (Azhar Arsyad, 2006: 3). According to Suranto (2005: 18) the media is "a means used to convey messages from a communicator to the communicant". Meanwhile according to Sutirman (2013: 15) the media is "a component of learning resources or physical vehicles containing instructional material in the student environment that can stimulate students to learn". Another opinion expressed by Sadiman (1996: 6) the media is "everything that can be used to channel messages from the sender to the recipient so that it can stimulate the thoughts, feelings, concerns, interests and attention of students in such a way that the learning process occurs". Meanwhile, according to Sukiman (2012: 29) what is meant by the media are: everything that can be used to channel messages from the sender to the recipient so as to stimulate the thoughts, feelings, concerns and interests and will of students in such a way that the learning process occurs in order to achieve learning objectives effectively.

Stern (1996: 20) explains that second language learning is a conscious study of second language development especially in formal schools. This is different from traditional language learning which focuses on language structure and elements such as vocabulary, pronunciation, and sentence structure. New methods of language learning now focus more on general communication skills and give greater priority to the ability to express them meaningfully and to make oneself understood rather than the accuracy of grammar or perfect pronunciation (Richard and Rogers, 2001: 19). To achieve this language learning goal, it is important to have all language skills: listening, speaking, reading and writing.

Thus the learning media is an intermediary used to convey information or lessons with the aim of stimulating students to learn. The use of instructional media is a way to convey information in the form of learning material. The existence of media is expected that the learning process will be easier for students, because learning media can overcome the limitations of space and time in learning, besides that the media can also provide motivation for students to learn.

This is to create a learning atmosphere that is fun and effective according to the real conditions of the community. It also benefits students as the next generation of the nation to be able to keep abreast of news from other countries. In addition, the Indonesian state is also maintained for its security and sovereignty.

This research aims to:

1. Knowing the process of teaching English using satellite TV media; and

English Teaching Journal, Vol. 7, No. 2, Desember 2019: 67 - 74 
2. Whether the use of satellite TV media can improve the students' English mastery.

This research is expected to provide benefits to:

1. Students can be able to master English in a more fun way.

2. Universities that want to provide different teaching media for teaching English.

3. Authorities to continue for providing support and regulations that facilitate the process of teaching English.

4. Government, as a reference to be able to follow the development of other countries.

\section{METHOD}

A. Research Approach

This research uses a Classroom Action Research (CAR). Classroom action research conducted here uses a model developed by Kemmis and McTaggart in Jakni (2017). The action research implementation model includes four steps as follows:

1. Identify problems and plan actions

2. Implement actions and observe or monitor actions

3. Reflecting the results of observations, and

4. Revise the plan for the next step

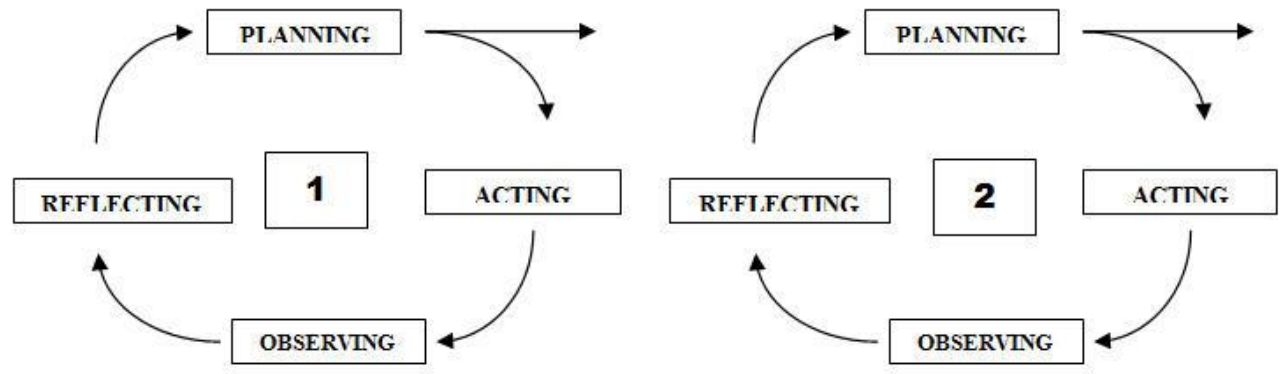

In this research, the researchers planned to use 2 cycles in the learning process. Learning process can be successful if the average score of students in the first cycle has increased compared with the score of the pre-test, and the average score of the second cycle has increased compared with the average score of the first cycle.

\section{B. Subjects of the Study}

The subjects of this research were the third semester of English education students of NU Sunan Giri Bojonegoro University in the academic year of 2019/2020. There are 35 students. This research was carried out in the room U8 of NU Sunan Giri University Bojonegoro.

C. Technique of Data Collection

In this classroom action research, researchers collected data using qualitative and quantitative methods. First, data collection techniques uses qualitative methods. The qualitative method consists of observations, field notes and interviews.

1. Observation

Researchers make observations related to the real situation of the teaching and learning process.

\section{Field Notes}

Researchers make notes in every observation. The researcher makes notes for all activities during the learning process and records students' reactions and responses to the learning.

3. Interview

The researcher conducts interviews from pre-research, in the course of action and at the end of the study. Interviews were conducted on students during the action process and at the end of the study aimed to determine the extent to which these actions affect students' understanding of English. 
Second, data collection techniques using quantitative methods are tests. In this study, researchers used a type of objective tests for pre-test and post-test. Test results were analyzed to determine the ability of students in mastering English.

D. Technique of Data Analysis

In analyzing qualitative data, researchers analyzed the results of observations made during the teaching and learning process using the Constant Comparative Method, including data reduction, data classification, data synthesis, and ending with the following action hypothesis:

1. Data Reduction

a) Unit identification. This is done by identifying the smallest unit found in the data. That must be a closed relationship with the research problem.

b) After getting the unit, the next step is to make the codification. This means that each unit must be coded to know where the data comes from.

2. Categorization

a) Categorization settings. This is intended to select each unit that has the same characteristics

b) Each category must be labeled.

3. Synthesis

a) Synthesizing means looking for relationships between one category and another.

b) Then related to one category with another must be labeled again.

4. State the 'Hypothesis of Action'

In analyzing data, researchers investigate field records that are made regularly. This action research will succeed if there is an increase in the average value of students in each cycle. Success can be seen when students can answer and take tests. In addition, student responses and reactions to lessons are better than before where they enjoyed and felt comfortable learning English in class.

Quantitative data were analyzed by comparing the mean values of the pre-test and post-test to find out the differences before and after the cycle. In analyzing data in the form of numbers as a result of the test, the researcher uses the average value of the pre-test and post-test. Then, researchers compare these scores. This increase can be seen from the post-test score which is higher than the score in the pre-test.

\section{FINDINGS AND DISCUSSION}

1. Description of Observation Results

a. Planning

Based on the results of the initial survey (pre-test), the problem that occurs was the lack of students' English mastery. To overcome this, the process of English learning will use satellite TV. The next step was the preparation of a lesson plan that included the use of satellite TV in learning. Planned channels are NHK, Channel News Asia, and France24.

\section{b. Acting}

The action was carried out in a prepared classroom. Learning began with greetings. Then proceed with questions and answers about satellite TV that will be used in learning. After that the TV channels were played through the TV with the help of a secondary display via the projector.

Students watched, observed, and resumed the programs being played. Each student then made a resume based on the program they have watched in English. Then each student conveyed what they have written. Other students responded, so questions and answers occurred. At the end of the lesson they drew conclusions from the material obtained in the learning activities.

c. Observing

During the lesson, every important event was recorded starting from the opening of the class until the end of learning. After observing, it was obtained the data of student activities during the learning process.

d. Reflecting

English Teaching Journal, Vol. 7, No. 2, Desember 2019: 67 - 74 
From the results of observations, data obtained weaknesses and strengths of the media used. Weaknesses during learning could also be identified, so they can be improved in the next cycle.

\section{Description of Quantitative Data}

The following are the results of the score starting from the pre-test, cycle I, and cycle II. Minimum graduation criteria is set at 7.5. After obtaining the data, these scores are then analyzed the increasing of the score. After that, a conclusion can be obtained from the use of satellite TV to master English.

1. Pre-test

Before conducting research, a pre-test is conducted to determine the state of students' mastery of English. Here are the results of the pre-test:

\begin{tabular}{|c|c|c|c|}
\hline No. & NAME & SCORE & INFORMATION \\
\hline 1 & $\mathrm{ACA}$ & 50 & FAILED \\
\hline 2 & A S & 55 & FAILED \\
\hline 3 & A L & 45 & FAILED \\
\hline 4 & $\mathrm{AN}$ & 60 & FAILED \\
\hline 5 & A M & 55 & FAILED \\
\hline 6 & A S 2 & 65 & FAILED \\
\hline 7 & D I & 70 & FAILED \\
\hline 8 & $\mathrm{DA}$ & 65 & FAILED \\
\hline 9 & D W & 55 & FAILED \\
\hline 10 & D S B & 70 & FAILED \\
\hline 11 & F H & 70 & FAILED \\
\hline 12 & J N F & 85 & PASSED \\
\hline 13 & M I P & 65 & FAILED \\
\hline 14 & M I B & 60 & FAILED \\
\hline 15 & N A P & 55 & FAILED \\
\hline 16 & NA A Z & 50 & FAILED \\
\hline 17 & N L & 75 & PASSED \\
\hline 18 & $\mathrm{OA}$ & 70 & FAILED \\
\hline 19 & R S S & 65 & FAILED \\
\hline 20 & R A S & 65 & FAILED \\
\hline 21 & S K & 55 & FAILED \\
\hline 22 & S M & 45 & FAILED \\
\hline 23 & S Q N N & 70 & FAILED \\
\hline 24 & S G S & 70 & FAILED \\
\hline 25 & S R & 70 & FAILED \\
\hline 26 & $\mathrm{SE}$ & 70 & FAILED \\
\hline 27 & U N F & 80 & PASSED \\
\hline 28 & W A N & 80 & PASSED \\
\hline 29 & $\mathrm{Z} \mathrm{N}$ & 75 & PASSED \\
\hline 30 & W R & 65 & FAILED \\
\hline 31 & M R M & 60 & FAILED \\
\hline 32 & I P S & 55 & FAILED \\
\hline 33 & E E A D P & 60 & FAILED \\
\hline 34 & T K & 45 & FAILED \\
\hline 35 & U K & 80 & PASSED \\
\hline
\end{tabular}

AVERAGE 63.71

In the pre-test, the number of students who passed was 6 students $(17.14 \%)$ with an average grade of 63.71 .

2. Cycle I

After the pre-test score were obtained, then cycle I was conducted. The results of the first cycle are:

\begin{tabular}{cccc}
\hline No. & NAME & SCORE & INFORMATION \\
\hline 1 & A C A & 60 & FAILED
\end{tabular}




\begin{tabular}{|c|c|c|c|}
\hline 2 & A S & 65 & FAILED \\
\hline 3 & $\mathrm{AL}$ & 70 & FAILED \\
\hline 4 & A N & 75 & PASSED \\
\hline 5 & A M & 75 & PASSED \\
\hline 6 & $\mathrm{~A} \mathrm{~S} 2$ & 80 & PASSED \\
\hline 7 & D I & 70 & FAILED \\
\hline 8 & D A & 70 & FAILED \\
\hline 9 & D W & 75 & PASSED \\
\hline 10 & D S B & 70 & FAILED \\
\hline 11 & F H & 75 & PASSED \\
\hline 12 & J N F & 85 & PASSED \\
\hline 13 & M I P & 75 & PASSED \\
\hline 14 & M I B & 65 & FAILED \\
\hline 15 & N A P & 65 & FAILED \\
\hline 16 & NA A Z & 70 & FAILED \\
\hline 17 & N L & 80 & PASSED \\
\hline 18 & $\mathrm{OA}$ & 75 & PASSED \\
\hline 19 & R S S & 70 & FAILED \\
\hline 20 & $\mathrm{RAS}$ & 65 & FAILED \\
\hline 21 & S K & 60 & FAILED \\
\hline 22 & S M & 60 & FAILED \\
\hline 23 & S Q N N & 80 & PASSED \\
\hline 24 & S G S & 75 & PASSED \\
\hline 25 & S R & 75 & PASSED \\
\hline 26 & S E & 75 & PASSED \\
\hline 27 & U N F & 85 & PASSED \\
\hline 28 & $\mathrm{~W}$ A N & 90 & PASSED \\
\hline 29 & $\mathrm{ZN}$ & 85 & PASSED \\
\hline 30 & W R & 70 & FAILED \\
\hline 31 & M R M & 70 & FAILED \\
\hline 32 & I P S & 75 & PASSED \\
\hline 33 & E E A D P & 75 & PASSED \\
\hline 34 & T K & 65 & FAILED \\
\hline 35 & U K & 80 & PASSED \\
\hline
\end{tabular}

In the first cycle, the number of students graduating was 19 students $(54.28 \%)$ with an average grade of 73 .

3. Cycle II

After the pre-test score were obtained, then cycle I was conducted. The results of the first cycle are:

\begin{tabular}{cccc}
\hline No. & NAME & SCORE & INFORMATION \\
\hline 1 & A C A & 70 & FAILED \\
\hline 2 & A S & 75 & PASSED \\
\hline 3 & A L & 75 & PASSED \\
\hline 4 & A N & 80 & PASSED \\
\hline 5 & A M & 75 & PASSED \\
\hline 6 & A S & 80 & PASSED \\
\hline 7 & D I & 75 & PASSED \\
\hline 8 & D A & 75 & PASSED \\
\hline 9 & D W & 75 & PASSED \\
\hline 10 & D S B & 75 & PASSED \\
\hline 11 & F H & 80 & PASSED \\
\hline 12 & J N F & 90 & PASSED \\
\hline 13 & M I P & 80 & PASSED \\
\hline 14 & M I B & 75 & PASSED \\
\hline 15 & N A P & 80 & PASSED \\
\hline 16 & N A A Z & 75 & PASSED \\
\hline 17 & N L & 85 & PASSED
\end{tabular}




\begin{tabular}{lccl}
18 & O A & 75 & PASSED \\
\hline 19 & R & 75 & PASSED \\
\hline 20 & R A S & 80 & PASSED \\
\hline 21 & S K & 75 & PASSED \\
\hline 22 & S M & 65 & FAILED \\
\hline 23 & S Q N N & 85 & PASSED \\
\hline 24 & S & 80 & PASSED \\
\hline 25 & S R & 85 & PASSED \\
\hline 26 & S E & 75 & PASSED \\
\hline 27 & U N F & 85 & PASSED \\
\hline 28 & W A N & 85 & PASSED \\
\hline 29 & Z N & 90 & PASSED \\
\hline 30 & W R & 75 & PASSED \\
\hline 31 & M R M & 75 & PASSED \\
\hline 32 & I P S & 75 & PASSED \\
\hline 33 & E E A D P & 80 & PASSED \\
\hline 34 & T K & 75 & PASSED \\
\hline 35 & U K & 90 & PASSED \\
\hline AVERAGE & & 78.43 &
\end{tabular}

In cycle II, the number of students who passed was 33 students $(94.28 \%)$ with an average score of 78.43.

4. Comparison of the score of Pre-test, Cycle I, and Cycle II

\begin{tabular}{|c|c|c|c|c|}
\hline No. & NAME & PRE-TEST & CYCLE I & CYCLE II \\
\hline 1 & A C A & 50 & 60 & 70 \\
\hline 2 & A S & 55 & 65 & 75 \\
\hline 3 & A L & 45 & 70 & 75 \\
\hline 4 & A N & 60 & 75 & 80 \\
\hline 5 & $\mathrm{AM}$ & 55 & 75 & 75 \\
\hline 6 & A S 2 & 65 & 80 & 80 \\
\hline 7 & D I & 70 & 70 & 75 \\
\hline 8 & D A & 65 & 70 & 75 \\
\hline 9 & D W & 55 & 75 & 75 \\
\hline 10 & D S B & 70 & 70 & 75 \\
\hline 11 & $\mathrm{FH}$ & 70 & 75 & 80 \\
\hline 12 & J N F & 85 & 85 & 90 \\
\hline 13 & M I P & 65 & 75 & 80 \\
\hline 14 & M I B & 60 & 65 & 75 \\
\hline 15 & N A P & 55 & 65 & 80 \\
\hline 16 & NAAZ & 50 & 70 & 75 \\
\hline 17 & N L & 75 & 80 & 85 \\
\hline 18 & $\mathrm{OA}$ & 70 & 75 & 75 \\
\hline 19 & R S S & 65 & 70 & 75 \\
\hline 20 & RAS & 65 & 65 & 80 \\
\hline 21 & S K & 55 & 60 & 75 \\
\hline 22 & S M & 45 & 60 & 65 \\
\hline 23 & SQ Q N & 70 & 80 & 85 \\
\hline 24 & S G S & 70 & 75 & 80 \\
\hline 25 & S R & 70 & 75 & 85 \\
\hline 26 & S E & 70 & 75 & 75 \\
\hline 27 & UNF & 80 & 85 & 85 \\
\hline 28 & W A N & 80 & 90 & 85 \\
\hline 29 & $\mathrm{ZN}$ & 75 & 85 & 90 \\
\hline 30 & W R & 65 & 70 & 75 \\
\hline 31 & M R M & 60 & 70 & 75 \\
\hline 32 & IP S & 55 & 75 & 75 \\
\hline 33 & E E A D P & 60 & 75 & 80 \\
\hline 34 & T K & 45 & 65 & 75 \\
\hline
\end{tabular}




\begin{tabular}{rrrrc}
35 & U K & 80 & 80 & 90 \\
\hline AVERAGE & 63.71 & 73 & 78.43
\end{tabular}

Based on the average score of the pre-test, cycle I, and cycle II, it can be concluded that the use of satellite TV can improve students' English mastery at NU Sunan Giri University Bojonegoro.

Teaching and learning process using satellite TV began with the preparation of lesson plan. After that the satellite TV is prepared in the classroom. Students watch the TV programs which were provided to them. The TV channels used are: NHK, Channel News Asia, and France24. All of the channels used English.

During watching TV, They have to write down the summary of the programs which they have watched. Each students has to present their work, some time they have to do it individually and some time in a group. Other students responded, so questions and answers occurred. At the end of the lesson they drew conclusions from the material obtained in the learning activities.

From the interview which has been conducted, almost all of the students agreed that learning English use Satellite TV was fun and enjoyable. It was different than if they read a book. satellite TV was more interactive. The programs varied from news, dialogues, entertainment, and even music. The use of satellite TV also made them could think differently and stimulate their ability in learning English. So they can easily understand the materials.

Their score had also increased. In the pre-test, the number of students who passed a total of 6 students $(17.14 \%)$ with an average score of 63.71. In the first cycle, the number of students who passed was 19 students $(54.28 \%)$ with an average score of 73 . In the second cycle, the number of students who passed was 33 students $(94.28 \%)$ with an average score of 78.43 .

\section{CONCLUSION}

The learning process of using Satellite TV in teaching English are: (1) Planning, the preparation of a lesson plan that included the use of satellite TV in learning; (2) Acting, Learning began with greetings. Then proceed with questions and answers about satellite TV that will be used in learning. After that the TV channels were played through the TV with the help of a secondary display via the projector. Students watched, observed, and resumed the programs being played. Each student then made a resume based on the program they have watched in English. Then each student conveyed what they have written. Other students responded, so questions and answers occurred. At the end of the lesson they drew conclusions from the material obtained in the learning activities, (3) Observing; During the lesson, every important event was recorded starting from the opening of the class until the end of learning. After observing, it was obtained the data of student activities during the learning process, (4) Reflecting, from the results of observations, data obtained weaknesses and strengths of the media used. Weaknesses during learning could also be identified, so they can be improved in the next cycle. The use of satellite TV can improve the students' English mastery at NU Sunan Giri University. In the pre-test, the number of students who passed a total of 6 students $(17.14 \%)$ with an average score of 63.71. In the first cycle, the number of students who passed was 19 students $(54.28 \%)$ with an average score of 73 . In the second cycle, the number of students who passed was 33 students $(94.28 \%)$ with an average score of 78.43 .

\section{References}

Azhar Arsyad. 2006. Media Pembelajaran. Jakarta: PT Raja Grafindo Persada.

Jakni. 2017. Penelitian Tindakan Kelas. Bandung: Alfabeta.

K-Vision. http://www.k-vision.tv/a/dapatkan-puluhan-channel-terbaru-termasuk-tv-lokal-tv-internasionalgratis-selamanya. Diakses 22 Agustus 2018

Narmadi, Umbul. 2016. Mengintip Canggihnya Sistem TV Satelit. (https://blog.narmadi.com/tv-satelit/ diakses 22 Agustus 2018)

Richard, Jack C. \& Rodgers, Theodore. 2001. Approaches and Methods in Language Teaching. Cambridge: Cambridge University Press.

Sardiman. 1996. Interaksi dan Motivasi Belajar Mengajar. Jakarta: Raja Grafindo Persada.

Stern, H. H. 1996. Fundamental Concept of Language Teaching. New York: Oxford University Press.

Sukiman. (2012). Pengembangan Media Pembelajaran. Yogyakarta: PT Pustaka Insan Madani.

Suranto. (2005). Komunikasi Perkantoran. Yogyakarta: Wahana Grafika.

Sutirman. (2013). Media dan Model-Model Pembelajaran Inovatif. Yogyakarta: Graha Ilmu. 